Svitlana Popova

Volodymyr Popov, Associate Professor, $\mathrm{PhD}$ in Economics (Candidate of Economic Sciences)

Central Ukrainian National Technical University, Kropyvnytskyi, Ukraine

\title{
Financial Support for the Development of Joint Territorial Communities
}

The theoretical bases of research of financial resources and financial support of development of territorial communities are analyzed in the article. The mechanism of their financial support by sources of financial resources is considered. An assessment of current state of the formation of financial and budgetary resources of joint territorial communities and their subsidization was made. The impact on financing of the development of joint territorial communities by the State Fund for Regional Development was analyzed. The basic requirements for the formation of an effective system of financial support for the development of joint territorial communities are formulated.

joint territorial community, financial resources, financial security, local budgets, subsidies, the State Fund for Regional Development, the community's own revenues

\section{С. П. Попова}

В. М. Попов, доц., канд. экон. наук

Центральноукраинский национальный технический университет, г. Кропивницкий, Украина

\section{Финансовое обеспечение развития объединенных территориальных общин}

В статье анализируются теоретические основы исследования финансовых ресурсов и финансового обеспечения развития территориальных общин. Рассмотрен механизм их финансового обеспечения по источникам финансовых ресурсов. Осуществлена оценка современного состояния формирования финансовых ресурсов бюджетов объединенных территориальных общин и их дотационность. Проанализировано влияние на финансирование развития объединенных территориальных общин со стороны Государственного фонда регионального развития. Сформулированы основные требования по формированию эффективной системы финансового обеспечения развития объединенных территориальных общин.

объединенная территориальная община, финансовые ресурсы, финансовое обеспечение, местные бюджеты, дотации, Государственный фонд регионального развития, собственные доходы общины

Statement of the problem. Current development of European integration processes in Ukraine needs to improve the quality of the formation of effective local self-government on the basis of decentralization of power and budget system. The considerable fragmentation of the majority of territorial communities and limited financial resources of these communities have led them to failure of fulfillment of their tasks. Some of them, especially in small settlements, quite often do not provide even elementary needs for human life.

The subsidization of a significant part of local budgets made them burdensome for the state budget and deprived territorial communities of incentives for socio-economic development. Therefore, the issue of association of territorial communities and search for and the expansion of sources for their effective development remains relevant. In that regard, the substantiation of theoretical foundations of financial support of joint territorial communities (JTCs) becomes especially relevant and promising to form the basis for the development of effective mechanisms for managing their development with the use of financial instruments.

Analysis of recent research and publications. Scientific works of many national economists are devoted to the study of problems of financial provision of territorial communities and the level of their financial capacity. In particular, I.Z. Storonianska and A.O. Pelekhatyi [12] study the issues of financial support for the development of territorial communities (in terms of budgetary relations) as the basis for increasing their financial capacity. V.P. Kosarina solves the problematic issues of the essence of financial resources of local authorities [6]. In the work [11] the financial capacity of a community is interpreted by

(C) Svitlana Popova, Volodymyr Popov, 2018 
the authors in a broad sense, and its dependence on the whole range of financial resources and incomes within and coming from the outside of a community is substantiated. M. A. Kovalenko, G.M. Schvorob, and T.O. Matsiyevych develop ways to improve the financial provision of activities of territorial communities [5]. L.V. Sukharska designs the mechanism of financial support for the development of territorial communities [13] and determines the state and features of financial support for the development of joint territorial communities in modern Ukraine on the basis of establishment of appropriate factor relations [14]. I. V. Abramova substantiates the content and forms of financial support of joint territorial communities and determines the most suitable ones of them [1]. All these and many other scientists considered different aspects of functioning of joint territorial communities and offered their own approaches to the financial provision of their development.

Though, scientific works tackled the problems of local finance, attention has been drawn repeatedly to the need to strengthen the decentralization of management of financial resources of the country, the expansion of the revenue base of local budgets, a more complete and independent financial support for the development of territories, but market conditions require constant search for rational financial security instruments for joint territorial communities.

Statement of the objective. The objective of this study is to synthesize theoretical approaches to the essence of financial support for the development of joint territorial communities and further scientific research on the ways of expanding the sources of their financing on this basis.

Main material. Financial resources of local self-government are the monetary revenues generated by distribution and redistribution of gross domestic product, monetary accumulations and monetary reserves (some of which are concentrated in the specific funds) necessary for local government bodies to perform their functions and tasks in order to ensure socio-economic functioning and development of territorial communities and meeting their common interests [6].

According to M.A. Kovalenko, G.M. Schvorob, T.O. Matsiyevych, "financial resources of a territorial community is a set of financial funds involved in the provision of community activities; the amount of financial resources represented by a local budget, by financial funds of a territorial community, by financial resources of local business entities and households". The authors support the viewpoint of N. Kolesnikova that financial resources of a territorial community encompass the following elements: own funds of business entities engaged in commercial activity in manufacturing and non-manufacturing sectors: funds of credit and financial regional institutions and of their affiliates in a region, as well as affiliates of financial and credit institutions and those operating in this region; funds of nongovernmental organizations or foundations engaged in non-profit activities in a region; funds of the population, including current monetary receipts and accumulations in various forms; funds of local budget [5, p. 28].

L.V. Sukharska believes that "financial support for the development of a territorial community" is a process of purposeful influence of all parties with which the territorial community interacts, to meet its needs and interests through the formation and use of financial resources. "A system of financial provision of development of territorial communities" is viewed by her as a set of interconnected elements necessary for the formation and use of financial resources in the process of ensuring the development of a territorial community [13].

I. Storonianska, A. Pelekhatyi came to the conclusion that the financial security of a territorial community is characterized, first of all, by the availability of appropriate financial resources and reflects the ability of local authorities to fulfill their statutory tasks. That is, financial security is a balance between the needs of a territorial community (including local self-government bodies) and its capabilities [12].

We share the following opinion of I. V. Abramova that the financial support of 
territorial communities should be understood as the process of formation, distribution and use of financial resources in order to meet the needs and interests of citizens in all spheres of life in a respective territory. In this case, budget funding remains the main form of financial provision of territorial communities. The quality of such funding depends on the level of economic and social development of a community [1, p. 14].

The need to define and substantiate sources of financial support of local selfgovernment acquires scientific and practical importance.

Financial resources of various economic agents, in particular local and central authorities, private entities, financial institutions and non-governmental organizations, as well as foreign states and international financial organizations may be used to meet requirements of JTCs. Financial resources may be classified according to different criteria: by territorial origin, regularity of use, economic content or method of attracting [2, p. 45].

Sources of funding for the development of territorial communities may be classified according to different criteria:

- origin:

- internal (local budgets, extrabudgetary funds of local self-government, funds of utility companies);

- external (transfers, investments, charitable help);

- regularity:

- regular (taxes, rental payments, lease payments);

- irregular (international technical assistance, grants, loans);

- one-time (land sales, privatization of communal property);

- source form:

- budget;

- investment;

- loan;

- grant [13].

Depending on the sources of funding for the development of joint territorial communities, the mechanisms for their financing are classified as shown in Figure 1.

It is worth noting that JTCs already form a rather significant sector in the structure of the administrative-territorial system. As of June 16, 2017, they united $22.5 \%$ of all territorial communities with a total area of $17.7 \%$ and the population close to $20 \%$ of the country's population. The activities of JTCs are quite widely covered in various analytical and scientific works. However, due to a rather short period of existence of JTCs, the statistical data set today is insufficient for full analysis. Thus, out of 524 created JTCs, only 159 had a completed budget cycle in 2016, when they developed and implemented their own budgets, which enable them to evaluate the impact of financial support on the development of communities.

Since the sufficiency of financial resources and the effectiveness of their use depends on the success of communities functioning, we will analyze the revenue part of their budgets.

The composition of the general fund revenues of joint territorial communities is defined in Art. 64 of the Budget Code of Ukraine as follows: $60 \%$ of the personal income tax; $50 \%$ of rent for special water use; excise tax on sale of excisable goods by business entities; $10 \%$ of the corporate profit tax (except profit tax of state and municipal enterprises); corporate and financial institutions of communal property income tax; other incomes [3].

During 2015-2016, the volume of actual revenues of the general fund of local budgets of JTCs of Ukraine (with transfers from the state budget) has increased by almost 6,5 times (from 1092.3 million UAH in 2015 to 7005.2 million UAH in 2016) [4]. The largest amount of income is observed in JTCs of the Khmelnytskyi region (an average of $18 \%$ of total revenues of JTCs in Ukraine), the lowest in JTCs of Kherson and Mykolayiv oblasts (an average of $0.2 \%$ ). 


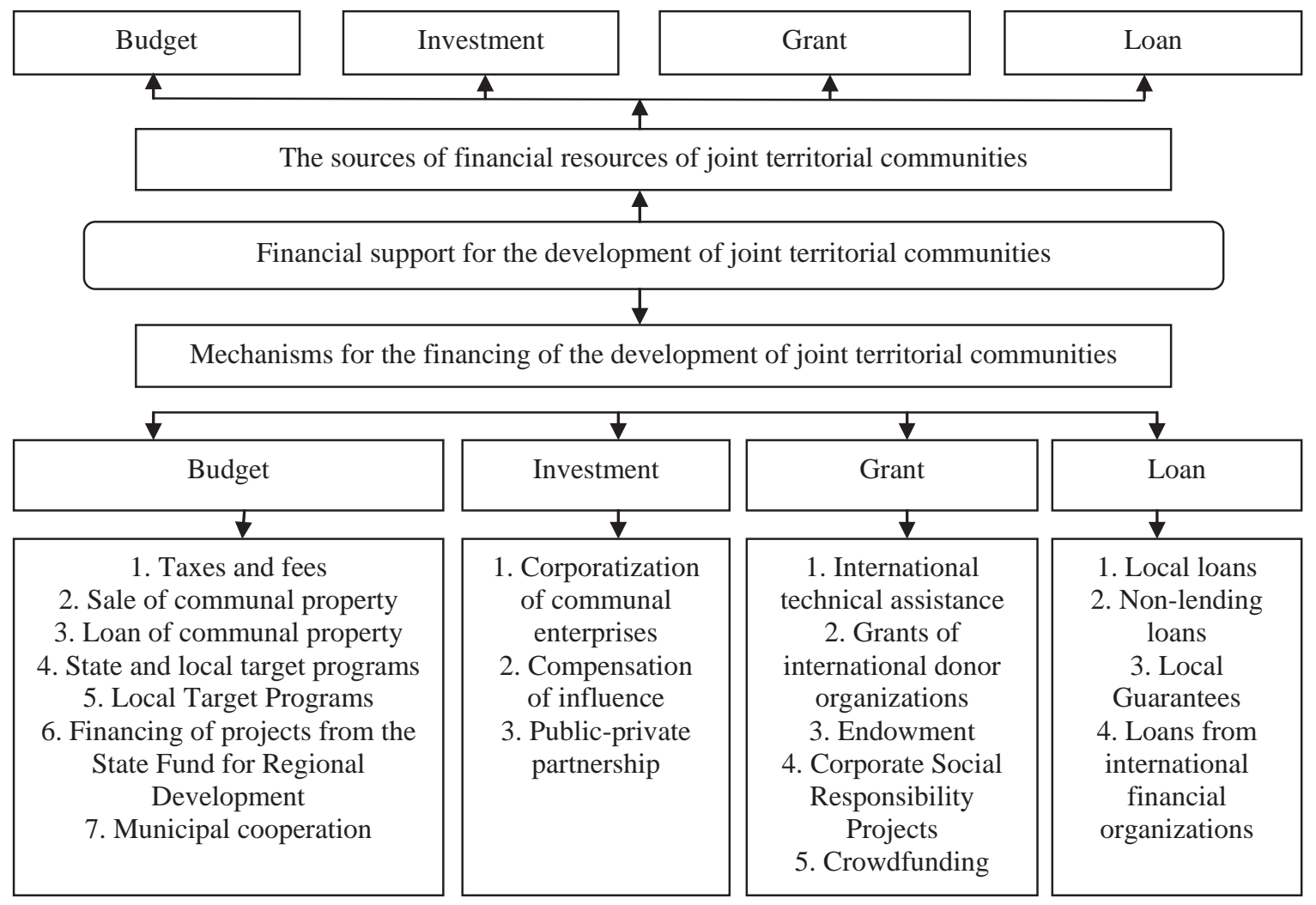

Figure 1 - Mechanisms for the financing of the development of joint territorial communities Source: developed by the author on the basis of [10].

Actual revenues of local budgets of JTCs consist of indicators of own resources and subventions that are provided to local budgets of JTCs from the state budget. In 2015, the main share of total revenues of JTCs in Ukraine (92.6\%) hold own resources in the amount of 1011.3 million UAH. In 2016, the amount of its own resources increased by 2 times (by UAH 2240.5 million), but their share in total revenue was $46.4 \%$ (the rest - subventions) [4].

One of the indicators that determines the financial capability of a JTC is the yield per person (Table 1).

Table 1 - Budget revenues for 1 person in JTCs in 2016

\begin{tabular}{|l|c|c|}
\hline \multicolumn{1}{|c|}{ Indicator } & Number of JTCs & Share, $\%$ \\
\hline More than 2,8 thousand UAH & 8 & 5,0 \\
\hline $2,1-2,8$ thousand UAH & 10 & 6,3 \\
\hline $1,4-2,1$ thousand UAH & 36 & 22,6 \\
\hline $0,7-1,4$ thousand UAH & 61 & 38,4 \\
\hline Less than 0,7 thousand UAH & 44 & 27,7 \\
\hline Total & 159 & 100,0 \\
\hline
\end{tabular}

Source: developed by the author using data from [4].

In general, 91 JTCs out of 159 have the earning yield index per person over 1 thousand UAH. The remaining 58 JTCs have lower rates of return. The average budget yield per person is $1,300 \mathrm{UAH}$, which in fact corresponds to the average national indicator of 1,4 thousand UAH. [4].

If we consider the budgets of newly formed JTCs in absolute terms, then their numbers are also impressive. For example, 3 JTCs have budgets of less than 1 million UAH and 36 other JTCs have budgets in the amount of 1 to 3 million UAH, and only 1/3 of the JTC budgets are over 10 million UAH. The average income of all JTCs is 11.7 million UAH. [4]. 
The most representative indicator of the financial capability of a JTC is the subsidization of their budgets (Table 2). It shows the real volume of budgeting of newly created JTCs.

Table 2 - Subsidy of JTC budgets in 2016

\begin{tabular}{|l|c|c|}
\hline \multicolumn{1}{|c|}{ Indicator } & Number of JTCs & Share, $\%$ \\
\hline More than 50\% & 22 & 13,8 \\
\hline $30,01-50,00 \%$ & 30 & 18,9 \\
\hline $10,01-30,00 \%$ & 52 & 32,7 \\
\hline Less than 10\% & 21 & 13,2 \\
\hline Not subsidized & 34 & 21,4 \\
\hline Total & 159 & 100,0 \\
\hline
\end{tabular}

Source: developed by the author using data from [4].

Only $22 \%$ of JTCs (34) have not a subsidized budget. Among subsidized budgets (125), $40 \%$ of JTCs (50) have a percentage of subsidies from $0.5 \%$ to $20 \%$; another $40 \%$ of JTCs (50) have a percentage of subsidies from $20 \%$ to $50 \%$ and $20 \%$ of JTCs (25) have subsidy percentage more than $50 \%$. The average subsidy of budgets of JTCs is $27.6 \%$ [4].

Analyzing the structure of own resources of local budgets of JTCs, it should be noted that if the main fillers in it were land payments (UAH 355.3 million) and the single tax (UAH 283.4 million) in 2015, then in 2016 the main share of own revenues of budgets took the Income Tax of Individuals (ITI) (1744.6 million UAH). This is due to the fact that with the beginning of the new fiscal year they switched to direct intergovernmental relations with the state, which provide not only the transfer of intergovernmental transfers, but also the provision of additional own financial resources, in particular, an increase in the percentage of transfer of above mentioned taxes and an additional $60 \%$ of the personal income tax, which was previously credited to the district budget. Thus, this tax became the main filler of budgets.

The object of taxation of the Income Tax of Individuals is the total monthly (annual) taxable income, income from sources of origin in Ukraine and foreign incomes received from sources outside Ukraine. This payment serves as a microeconomic stabilizer and regulator of financial support for community development. There is, therefore, a correlation between the development of economic activity in a community, the income of population and the income from the Income Tax of Individuals to local budgets of territorial communities.

The realities of the present testify to the presence of the following problems in the development of joint territorial communities and in the provision of income from taxation of the ITI on a territory concerned:

- the main source of income from ITI is an allocation from wages of employees of budgetary institutions which testifies to low economic activity within the framework of JTC;

- inefficiency of using own economic potential and low efficiency of activity on attraction of economic entities to functioning on the territory of a community;

- reduction of local budget revenues from ITI due to the optimization of networks of educational and healthcare establishments in a number of JTCs (the process of decentralization and administrative-territorial reform are being implemented simultaneously with a number of sectoral reforms that involve the closure of some schools and healthcare institutions that do not meet the requirements or reduce the number of their staff) $[15$, p. $67-$ $68]$.

As for the share of subventions from the state budget, in 2015 the subvention was granted only to the JTCs of Donetsk region (UAH 81 million). However, in 2016, the situation changed dramatically: subventions took the bulk of total JTC budgets $(53.6 \%)$ of their own resources and were provided to each of the JTC budgets.

In general, the analysis shows that the overall picture of JTC activity in Ukraine is 
positive. They are moving in the right direction to achieve the maximum level of their financial autonomy.

The existence of an incentive for communities to unite is worth mentioning, as the formation of capable territorial communities takes place through the mechanism of transition of budgets of communities to direct intergovernmental relations with the state budget, empowerment of such communities with powers equivalent to powers of cities of oblast importance, deprivation of the right to perform powers of local self-government bodies delegated by the state in villages, settlements, towns of district significance that have not been united.

An important step in strengthening of financial base of joint territorial communities was the creation of the State Fund for Regional Development (SFRD), which envisages financing of regional development projects on a competitive basis and in accordance with regional development strategies and action plans for their implementation. The funds of the State Fund for Regional Development are directed to implement investment programs and regional development projects (including projects of cooperation and voluntary association of territorial communities) aimed at the development of regions, creation of infrastructure of industrial and innovative parks and meet the priorities defined in the Regional Development Strategy of the state and relevant regional development strategies [9]. Programs and projects implemented at the expense of the SFRD are subject to co-financing from local budgets at the level of 10 percent. The specified condition is a motive for finding these resources and more efficient use of them by a community. It is important to emphasize that when developing and presenting programs and projects to the SFRD, communities should realize the importance of directing most of them not only to targeted restoration or development of infrastructure, but to implement the State Strategy for Regional Development and strategies of regions and to create additional economic value and economic development of a region [16].

So, in 2017433 projects were implemented for the total amount of UAH 1159.1 million using the funds of the SFRD. 6 JTC projects from this list with a total value of 11792.2 thousand UAH, in which the contribution of SFRD amounted to 8214.0 (69.7\%), were implemented. Four of these projects were aimed at the formation of secondary educational institutions (capital repairs and reconstruction of schools) and one of them - to the development of health sector. In addition to the above, six JTC projects are in the process of implementation. Their total cost is UAH 24,674.4 thousand, of which the contribution of the SFRD is $17,909.1(72.6 \%)$. The aforementioned projects are aimed at the reconstruction of administrative buildings and social infrastructure, as well as for repairing of transport infrastructure of localities [8].

The main attention in the vast majority of scientific publications concerning the formation of local community incomes is paid to the budget resources. However, we believe it is worthwhile to emphasize the importance of non-budget sources of financial resources, which should play a significant role in ensuring the financial capacity of territorial communities and should be considered as an integrated indicator of its budget capacity, financial capacity of households and financial capacity economic entities, which together form the financial capacity of a territorial community in a broad sense [11, c. 84].

Strengthening of financial capacity of territorial communities and their economic development depends on the effectiveness of the use of assets owned and managed by a community. Assets of a territorial community include the right of communal ownership to immovable and movable property, natural resources, land, business structures, revenues of local budgets, etc. Therefore, the development of a territory is possible only on the condition of effective use of its internal potential, which involves the capitalization of assets and the creation of value added. The development of entrepreneurial structures in a territory of an administrative-territorial unit allows to ensure, firstly, creation of jobs, and secondly, the increasing of tax revenues to a local budget, and thirdly, the formation of social responsibility 
of business to a community. Therefore, the formation of practice of social responsibility of business to the community can ensure its rapid development [15, p. 73].

Funds from community residents, including those received abroad (income of migrant workers), can also become a source of development. It should be acknowledged that firstly such funds are used by households for their own needs (children's education, repairs, purchase of real estate, improvement of their own land plots, etc.). However, it is important to realize feasibility and possibility of directing these resources into structured long-term projects that will have a multiplier effect on a whole community (creation of enterprises, farms, agricultural service cooperatives, infrastructure development and public places improvement). However, for this purpose, it is important for citizens and a community as a whole to understand the need to form an appropriate market and investment environment, infrastructure development, etc., as well as changes in mentality and outlooks [16].

Further steps to strengthen the material and financial base of territorial communities lie in the area of analysis of results, the identification and solution of problematic issues of fiscal decentralization in order to strengthen the community's financial resources, the formation of legislative support for reforms in the areas of land relations and management of communal property.

It is necessary to encourage territorial communities to use their right to borrowing both local and foreign, and obtaining loans from international financial organizations. These funds are directed to implementation of investment programs aimed at development of communal infrastructure, implementing resource-saving technologies, creating, enhancing or updating strategic objects of long-term use or objects that ensure the fulfillment of tasks of local councils in order to meet the interests of their communities . To attract external nonbudget resources to finance local development, it is necessary to work on creating a positive image of a territory, forming its attractive "credit" history.

An endowment mechanism can be perspective for funding the development of territorial communities. This is a trust fund intended for non-commercial purposes, usually for the purpose of financing organizations and initiatives in the field of education, health care or culture (primarily in terms of labor potential development), which is funded through charitable donations. Community members must be proactive and constantly offer their own ideas, invite local fellow countrymen, celebrities to local events, which can result in their support (and not only financial). In order to accelerate the process of forming of endowment funds in Ukraine it is necessary to take foreign experience into account and to amend the Tax and Budget Codes to provide taxpayers with tax privileges and state benefits [10].

The innovative tool for financing the development of territorial communities is crowdsourcing. It is a combination of idea of self-help and modern information technology in order to address societal challenges and local issues with broad public participation. In our opinion, the success of projects of crowdsourcing depends, first of all, on the size of social capital of a community, which, in turn, depends on a community's experience in joint resolution of its problems [7]. To this end, local authorities should involve active, skilled, qualified specialists interested in its development.

A special kind of crowdsourcing is crowdfunding, which is aimed at collecting voluntary donations or investments for implementation of certain projects. Creation of the website "Shpilnokosht" was the first crowdfunding project in Ukraine. The authors collected 30 thousand UAH for development of the site. To date, Ukrainians have invested more than 10 million UAH, more than 21 thousand people have been involved in this business and 157 projects have been funded by it. The following areas are supported by "Spilnokosht": education, ecology, social services, entrepreneurship and innovations [10].

Consequently, an increase in volume of financial resources at the disposal of local governments and the formation of their financial capacity is possible due to introduction of a new model of financial provision of territorial communities. 
Conclusions and prospects for further research. It is identified that budget financing remains the main form of financial support of joint territorial communities. Its quality depends on the level of economic and social development of these communities. The insufficiency of budget financing of territorial communities necessitates the search for alternative sources of their financial support.

It is necessary to encourage territorial communities to use their right to borrowing both local and foreign, and obtaining loans from international financial organizations. Advisory activities with local government bodies shall be conducted to this end. They shall have enough technical expertise to use such source of funding effectively and to simplify the process of preparing documentation for obtaining such loans. Such mechanisms as endowment and crowdsourcing may be perspective for financing of development of territorial communities. The use of concrete tools and mechanisms on practice depends on the specifics of the development of a community, its capabilities and problem situations.

In order to ensure an effective development of joint territorial communities, the prospects for further research should focus on substantiation of directions of expansion of their financial base, formation of ways of encouraging entrepreneurial initiatives, effective use of local resources, creation of new jobs, etc.

\section{Список літератури}

1. Абрамова I.В. Теоретичне обгрунтування змісту та форм фінансового забезпечення об'єднаних територіальних громад [Текст] / I.В. Абрамова //Вісник Житомирського національного агроекологічного університету. - 2017. - № 1 (59), т. 2. - С. 9-18.

2. Богун К.В. Алгоритм створення і реалізації програми маркетингу і брендингу міста [Текст] / К.В. Богун / Экономика и управление. - 2013. - №2. - С. 40-45.

3. Бюджетний кодекс України від 08.07.2010 p. №2456-VI (зі змінами та доповненнями). [Електронний ресурс]. - Режим доступу: http://zakon2.rada.gov.ua/laws/show/2456-17/page7

4. Децентралізація. Місцеві бюджети 159 об'єднаних територіальних громад. 2016 рік [Електронний peсурс] - Режим доступу: http://www.minregion.gov.ua/wp-content/uploads/2017/04/Decentr_297x210_April-2017.pdf

5. Коваленко М.А. Шляхи поліпшення фінансового забезпечення діяльності територіальних громад [Електронний ресурс]. / М.А. Коваленко, Г.М. Швороб, Т.О. Мацієвич // Теорія та практика державного управління і місцевого самоврядування. - 2014. - № 1. - Режим доступу: http://nbuv.gov.ua/UJRN/Ttpdu_2014_1_23

6. Косаріна В.П. Економічна природа та сутність фінансових ресурсів органів місцевого самоврядування: проблемні питання [Текст] / В.П. Косаріна, О.В. Тимошенко // Фінанси України. - 2010. - № 5. - С. 118-125.

7. Карий О.І. Місцеві ініціативи та залучення громадськості до здійснення місцевого самоврядування. Навчальний посібник для посадових осіб місцевого самоврядування [Текст] / O.I. Карий, Я.В. Панас / Асоціація міст України - К., ТОВ «ПІДПРИСМСТВО «ВІ ЕН ЕЙ», 2015. - 176 c.

8. Перелік проектів Державного фонду регіонального розвитку [Електронний ресурс]. - Режим доступу: http://dfrr.minregion.gov.ua/Projects-list

9. Про Державний фонд регіонального розвитку [Електронний ресурс]. / Офіційний сайт Державного фонду регіонального розвитку; Міністерство регіонального розвитку, будівництва та житловокомунального господарства України. - Режим доступу: http://dfrr.minregion.gov.ua/pro-konkurs

10. Ресурсне забезпечення об'єднаної територіальної громади та ії маркетинг: навч. посіб. [Текст] / [Г.А. Борщ, В.М. Вакуленко, Н.М. Гринчук, Ю.Ф. Дехтяренко, О.С. Ігнатенко, В.С. Куйбіда, А.Ф. Ткачук, В.В. Юзефович] - К.: - 2017. - 107 с.

11. Сембер С.В. Теоретичні підходи до визначення сутності фінансової спроможності та фінансових ресурсів територіальної громади [Текст] / С.В. Сембер, О.Г. Чубарь, К.С. Машіко // Регіональна економіка. - 2015. - №3(77). - С. 81-90.

12. Сторонянська I.3. Фінансове забезпечення розвитку територіальних громад у контексті адміністративно-територіальної реформи [Текст] / I.3. Сторонянська, А.О. Пелехатий // Регіональна економіка. - 2014. - №3(73). - С. 228-238.

13. Сухарська Л.В. Елементи системи фінансового забезпечення розвитку територіальної громади [Електронний ресурс] / Л.В. Сухарська // Вісник Нац. акад. держ. управління при Президентові 
України. - 2016. - № 1. - С. 119-125. - Режим доступу: http://nbuv.gov.ua/UJRN/vnaddy_2016_1_17

14. Сухарська Л.В. Аналіз стану фінансового забезпечення розвитку об'єднаних територіальних громад у сучасній Україні [Електронний ресурс] / Л.В. Сухарська // Державне управління: теорія та практика. - 2017. - № 1. - C. 92-101. - Режим доступу: http://www.epatp.academy.gov.ua/pages/dop/19/files/fb4bab59-69c4-415d-b4b0-cac93834d1ba.pdf

15. Територіальний розвиток та регіональна політика в Україні: актуальні проблеми, ризики та перспективи адміністративно-фінансової децентралізації: наукова доповідь [Електронний ресурс] / ДУ «Інститут регіональних досліджень імені М. І. Долішнього НАН України»; наук. редактор В.С. Кравців. - Львів, 2017. - 120 с. - Режим доступу: http://ird.gov.ua/irdp/p20170701.pdf

16. Чубарь О.Г., Машіко К.С. Децентралізація і фінансове забезпечення територіальної громади [Текст] / О.Г. Чубарь, К.С. Машіко // Науковий вісник Ужгородського університету. - 2016. - Вип. 1 (47). - T.1. - C.419-426.

\section{References}

1. Abramova, I.V. (2017). Teoretychne obgruntuvannia zmistu ta form finansovoho zabezpechennia ob'iednanykh terytorial'nykh hromad [The theoretical substantiation of content and forms of financial support of joint territorial communities]. Visnyk Zhytomyrs'koho natsional'noho ahroekolohichnoho universytetu - The Bulletin of Zhytomyr National Agroecological University, Vol. 2, 1(59), 9-18 [in Ukrainian].

2. Bohun, K.V. (2013). Alhorytm stvorennia i realizatsii prohramy marketynhu i brendynhu mista [The algorithm of creating and implementing a program of marketing and branding of a city]. Ekonomyka $y$ upravlenye - Economics and management, 2, 40-45 [in Ukrainian].

3. Biudzhetnyj kodeks Ukrainy (2010). [The Budget Code of Ukraine]. zakon2.rada.gov.ua. Retrieved from http://zakon2.rada.gov.ua/laws/show/2456-17/page7 [in Ukrainian].

4. Detsentralizatsiia. Mistsevi biudzhety 159 obiednanykh terytorialnykh hromad. 2016 [Decentralization of local budgets 159 united territorial communities. 2016]. Retrieved from http://www.minregion.gov.ua/wp-content/uploads/2017/04/De-centr_297x210_April-2017.pdf [in Ukrainian].

5. Kovalenko, M.A., Shvorob, H.M., \& Matsiievych, T.O. (2014). Shliakhy polipshennia finansovoho zabezpechennia diial'nosti terytorial'nykh hromad [Ways to improve the financial support of territorial communitie]. Teoriia ta praktyka derzhavnoho upravlinnia i mistsevoho samovriaduvannia - The theory and practice of public administration and local self-government, 1, Retrieved from http://nbuv.gov.ua/UJRN/Ttpdu_2014_1_23 [in Ukrainian].

6. Kosarina, V.P., \& Tymoshenko, O.V. (2010). Ekonomichna pryroda ta sutnist' finansovykh resursiv orhaniv mistsevoho samovriaduvannia: problemni pytannia [The economic nature and essence of financial resources of local self-government bodies: problematic issues]. Finansy Ukrainy - Finanses of Ukraine, 5, 118-125 [in Ukrainian].

7. Karyj, O.I., \& Panas, Ya.V. (2015). Mistsevi initsiatyvy ta zaluchennia hromads'kosti do zdijsnennia mistsevoho samovriaduvannia. Navchal'nyj posibnyk dlia posadovykh osib mistsevoho samovriaduvannia [Local initiatives and involvement of the public in the implementation of local self-government. A manual for local self-government officials]. Asotsiatsiia mist Ukrainy - Kyiv: TOV «PIDPRYYeMSTVO «VI EN EJ» [in Ukrainian].

8. Perelik proektiv Derzhavnoho fondu rehionalnoho rozvytku [List of projects of the State Fund for Regional Development]. dfrr.minregion.gov.ua. Retrieved from http://dfrr.minregion.gov.ua/Projects-list [in Ukrainian].

9. Pro Derzhavnyj fond rehional'noho rozvytku. Ofitsijnyj sajt Derzhavnoho fondu rehional'noho rozvytku; Ministerstvo rehional'noho rozvytku, budivnytstva ta zhytlovo-komunal'noho hospodarstva Ukrainy [About the State Fund for Regional Development. Official website of the State Fund for Regional Development; Ministry of Regional Development, Construction and Housing and Communal Services of Ukraine]. dfrr.minregion.gov.ua. Retrieved from http://dfrr.minregion.gov.ua/pro-konkurs [in Ukrainian].

10. Borsch, H.A., Vakulenko, V.M., Hrynchuk, N.M., Dekhtiarenko, Yu.F., Ihnatenko, O.S. \& Kujbida, V.S., et al. (2017). Resursne zabezpechennia ob'iednanoi terytorial'noi hromady ta ii marketynh: navchal'nyj posibnyk [The resource provision of a joint territorial community and its marketing: manual]. Kyiv [in Ukrainian].

11. Sember, S.V., Chubar', O.H., \& Mashiko K.S. (2015). Teoretychni pidkhody do vyznachennia sutnosti finansovoi spromozhnosti ta finansovykh resursiv terytorial'noi hromady [The theoretical approaches to the definition of the essence of financial capacity and financial resources of a territorial community]. Rehional'na ekonomika - The regional economy, 3(77), 81-90 [in Ukrainian].

12. Storonians'ka, I.Z., \& Pelekhatyj, A.O. (2014). Finansove zabezpechennia rozvytku terytorial'nykh hromad u konteksti administratyvno-terytorial'noi reformy [Financial support of the development of local 
communities in the context of the administrative-territorial reform]. Rehional'na ekonomika - Regional Economy, 3(73), 228-238 [in Ukrainian].

13. Sukhars'ka, L.V. (2016). Elementy systemy finansovoho zabezpechennia rozvytku terytorial'noi hromady [Elements of financial support system for the development of the territorial community]. Visnyk NADU pry Prezydentovi Ukrainy - NADA Bulletin under the President of Ukraine, 1, 119-125. Retrieved from http://nbuv.gov.ua/UJRN/vnaddy_2016_1_17 [in Ukrainian].

14. Sukhars'ka, L.V. (2017). Analiz stanu finansovoho zabezpechennia rozvytku ob'iednanykh terytorial'nykh hromad u suchasnij Ukraini [The analysis of the state of financial support for the development of joint territorial communities in modern Ukraine]. Derzhavne upravlinnia: teoriia ta praktyka - Public Administration: Theory and Practice, 1, 92-101. Retrieved from http://www.epatp.academy.gov.ua/pages/dop/19/files/fb4bab59-69c4-415d-b4b0-cac93834d1ba.pdf [in Ukrainian].

15. Kravtsiv, V.S. (Eds.). (2017). The territorial development and regional policy in Ukraine: current problems, risks and prospects for administrative and financial decentralization: scientific report, L'viv. ird.gov.ua. Retrieved from http://ird.gov.ua/irdp/p20170701.pdf [in Ukrainian].

16. Chubar, O.H., \& Mashiko, K.S. (2016). Detsentralizatsiia i finansove zabezpechennia terytorial'noi hromady [The decentralization and financial support of a territorial community] Naukovyj visnyk Uzhhorods'koho universytetu - The scientific bulletin of Uzhgorod University, Vol. 1, 1(47), 419-426 [in Ukrainian].

\section{С. П. Попова}

В. М. Попов, доц., канд. екон. наук

Центральноукраӥнський національний технічний університет, м. Кропивницький, Україна

\section{Фінансове забезпечення розвитку об'сднаних територіальних громад}

Дотаційність значної частини місцевих бюджетів зробило їх обтяжливими для державного бюджету та позбавило територіальні громади стимулів до соціально-економічного розвитку. Тому питання об'єднання територіальних громад та пошуку й розширення джерел їх ефективного розвитку зберігають свою актуальність. Метою даного дослідження є узагальнення теоретичних підходів щодо сутності фінансового забезпечення розвитку об'єднаних територіальних громад та на цій основі подальший науковий пошук напрямків розширення джерел їх фінансування.

Під фінансовим забезпеченням територіальних громад слід розуміти процес формування, розподілу та використання фінансових ресурсів, з метою задоволення потреб та інтересів громадян в усіх сферах життєдіяльності на відповідній території. При цьому, основною формою фінансового забезпечення територіальних громад залишається бюджетне фінансування, від якості якого залежить рівень іх економічного та соціального розвитку. Крім бюджетних джерел фінансового забезпечення об'єднаних територіальних громад можуть використовуватися інвестиційні, грантові та кредитні. Важливим кроком у зміцненні фінансової бази об'єднаних територіальних громад стало створення Держаного фонду регіонального розвитку, кошти якого спрямовуються на виконання інвестиційних програм і проектів регіонального розвитку (у тому числі проектів співробітництва та добровільного об'єднання територіальних громад), що мають на меті розвиток регіонів, створення інфраструктури індустріальних та інноваційних парків.

Недостатність бюджетного фінансування територіальних громад зумовлює необхідність пошуку альтернативних джерел їх фінансового забезпечення. Необхідно стимулювати територіальні громади до використання свого права на здійснення запозичень як місцевих, так і зовнішніх, в тому числі шляхом отримання кредитів (позик) від міжнародних фінансових організацій. Перспективними для територіальних громад можуть бути такі механізми фінансування їх розвитку як ендавмент та краудсорсинг. Використання певних інструментів та механізмів залежить від специфіки розвитку конкретної громади, іiї можливостей та проблемних ситуацій. Перспективи подальших досліджень мають бути спрямовані на пошук напрямів розширення їх фінансової бази, формування шляхів заохочення підприємницької ініціативи, ефективного використання місцевих ресурсів, створення нових робочих місць тощо.

об'сднана територіальна громада, фінансові ресурси, фінансове забезпечення, місцеві бюджети, дотації, Державний фонд регіонального розвитку, власні доходи громади 